\section{Optimum Planting Time, Plant Spacing, and Nitrogen and Potassium Rates to Maximize Yield of Green Cauliflower}

\author{
A.A. Csizinszky \\ Gulf Coast Research and Education Center, University of Florida, Institute of \\ Food and Agricultural Sciences, 5007 60th Street East, Bradenton, FL 34203
}

Additional index words. Broccoflower, subtropics, full-bed polyethylene mulch, Brassica oleracea L. Botrytis Group cv. Alverda

\begin{abstract}
Green cauliflower (Broccoflower) (Brassica oleracea L. Botrytis Group cv. Alverda) is a relatively new vegetable crop in the United States. Experiments were initiated to investigate the yield potential of 'Alverda' green cauliflower in three consecutive plantings (10 Oct. and 24 Nov. 1992 and 12 Jan. 1993) at two in-row spacings (31- and 38cm) with the factorial combinations of $\mathrm{N}$ and $\mathrm{K}$ at 98, 196, and $294 \mathrm{~kg} \cdot \mathrm{ka}^{-1}$ under subtropical conditions. Crops were grown in an Eau Gallie fine sand with the full-bed polyethylene mulch-seepage (modified furrow) irrigation system. Marketable yields were highest in the January planting with $\mathrm{N}$ at $294 \mathrm{~kg}^{\circ} \mathrm{ha}^{-1}$ when $71 \%$ of the plants had marketable size $(\geq 0.34 \mathrm{~kg})$ and desirable quality curds. Yields were higher at 38- than at 31-cm spacing. Yields and curd size increased with increasing $\mathrm{N}$ rates at all three planting dates $(P \leq 0.01)$. Potassium rates had no significant effect on yields.
\end{abstract}

Green cauliflower (Broccoflower) is a relatively new vegetable in the United States. The curd looks like that of a white cauliflower, but is light green. The curd is less dense and the buds on the florets are not as tightly packed as in white cauliflower. Green cauliflower is an excellent source of vitamin $\mathrm{C}$ and folic acid (Montecalvo, 1989). The vegetable industry in Florida is interested in growing high-value crops during the winter, but yields of cruciferous crops are often adversely affected by fluctuating temperatures (Csizinszky, 1987; Csizinszky and Schuster, 1988). Green cauliflower is a high-value crop, but very little is known of its optimum planting time, plant spacing, and nutrient requirements. In the Netherlands, the quality of green cauliflower is rather poor during the summer months but improves in the fall (Long, 1994). In a cultivar $\times$ spacing trial, Csizinszky (1995) found that 'Alverda' green cauliflower curd size was largest at $46 \mathrm{~cm}$ in-row spacing. The same cultivar in a winter-spring (30 Jan. to $17 \mathrm{Apr}$.) study (Csizinszky, 1996) gave the highest yield with $\mathrm{N}$ at $197 \mathrm{~kg} \cdot \mathrm{ha}^{-1}$ and at $31-\mathrm{cm}$, within-row spacing, but only $28 \%$ of the plants were of marketable-size $(>0.34 \mathrm{~kg})$ curds. Potassium rates did not affect marketable yields.

White cauliflower yields under cool climatic conditions were similar with $\mathrm{N}$ at 110 or $220 \mathrm{~kg} \cdot \mathrm{ha}^{-1}$ (Cutcliffe and Munroe, 1976; Dufault and Waters, 1985). In Florida, 'Snow Crown Hybrid' white cauliflower yields increased linearly when $\mathrm{N}$ rates were increased

Received for publication 18 Dec. 1995. Accepted for publication 11 May 1996. Florida Agricultural Experiment Station Journal Series no. R-04884. The cost of publishing this paper was defrayed in part by the payment of page charges. Under postal regulations, this paper therefore must be hereby marked advertisement solely to indicate this fact. from 128 to $256 \mathrm{~kg} \cdot \mathrm{ha}^{-1}$. Average weight per curd also increased from $0.74 \mathrm{~kg}$ with $128 \mathrm{~N}$ to $0.91 \mathrm{~kg}$ with $\mathrm{N}$ at $256 \mathrm{~kg} \cdot \mathrm{ha}^{-1}$ (Csizinszky, 1987; Csizinszky and Schuster, 1988). Wider within-row spacing resulted in increased curd size and yield. For example, in Florida, curd size was significantly larger at 46 than $31-\mathrm{cm}$, within-row spacing (Csizinszky, 1982), and in Minnesota, Dufault and Waters (1985) reported a linear increase in curd size when within-row spacing increased from 15 to 46 $\mathrm{cm}$. Since no reports were found on timing and only one season's data on yields, experiments were conducted to investigate the yield potential of green cauliflower at various planting times, plant populations, and $\mathrm{N}$ - and K-rate combinations.

\section{Materials and Methods}

Studies were conducted at the Gulf Coast Research and Education Center, Bradenton, Fla., on Eau Gallie fine sand (sandy, siliceous, hyperthermic Alfic Haplaquod) during the fallwinter-spring (Oct. 1992 to Apr. 1993). Soil samples collected before land preparation were analyzed at the Univ. of Florida Analytical Research Laboratory at Gainesville (Hanlon et al., 1990). The soil had a water $\mathrm{pH}$ of 6.98 , and (in mg.kg ${ }^{-1}$ ) $21.4 \mathrm{P}, 14.7 \mathrm{~K}, 669 \mathrm{Ca}$, and $106 \mathrm{Mg}$. Nitrogen was determined by the Kjeldahl method (Tecator, 1987) and the concentration (in mg. $\mathrm{kg}^{-1}$ ) of $\mathrm{NH}_{4}-\mathrm{N}$ and $\mathrm{NO}_{3}-\mathrm{N}$ was 0.5 and 1.0, respectively. The design was a split-split-split plot. Production system was the full-bed polyethylene mulch with seepage irrigation (Geraldson et al., 1965). Main plots were three planting dates: 1 Oct. and 24 Nov. 1992 and 12 Jan. 1993. Subplots, each $48 \mathrm{~m}$ long and $1.53 \mathrm{~m}$ wide, were two within-row spacings: 31.5 and $38.0 \mathrm{~cm}$. Sub-subplots, rates: 98, 196, and $294 \mathrm{~kg} \cdot \mathrm{ha}^{-1}$. Sub-sub-subeach $16 \mathrm{~m}$ long and $1.53 \mathrm{~m}$ wide, were three $\mathrm{N}$ plots, each $5.33 \mathrm{~m}$ long and $1.53 \mathrm{~m}$ wide, were three K rates: 98 , 196, and $294 \mathrm{~kg} \cdot \mathrm{ha}^{-1}$. Treatments (spacings and the $\mathrm{N}$ and $\mathrm{K}$ rates) in each of the three planting dates were randomized, arranged in a complete block, and replicated three times. Nitrogen source was $\mathrm{NH}_{4} \mathrm{NO}_{3}$, and $\mathrm{K}$ was derived from $\mathrm{KCl}(52.4 \% \mathrm{~K})$ and $\mathrm{K}_{2} \mathrm{SO}_{4}$. Phosphorus from a $0 \mathrm{~N}-8.74 \mathrm{P}-0 \mathrm{~K}$ superphosphate was applied at $51 \mathrm{~kg} \cdot \mathrm{ha}^{-1}$. The superphosphate also contained micronutrient frit (F503 oxide) at $27.6 \mathrm{~kg} \cdot \mathrm{ha}^{-1}$ that provided (in kg.ha ${ }^{-1}$ ) 2.0 B, 2.0 Cu, 12.1 Fe, 5.1 Mn, 0.15 Mo, and $4.7 \mathrm{Zn}$.

The superphosphate was placed in a 20 $\mathrm{cm}$-wide band on the false bed, and the $\mathrm{N}$ and $\mathrm{K}$ fertilizers were placed in a 5-cm-deep narrow furrow in the center of the 72-cm-wide and $20-\mathrm{cm}$-high beds. Soil was fumigated with $66.6 \%$ methyl bromide and $33.3 \%$ chloropicrin at $234 \mathrm{~kg} \cdot \mathrm{ha}^{-1}$, then covered with a 0.038 mm-thick white-on-black polyethylene film in the October planting and black polyethylene film in the November and January plantings. Two weeks later, on 1 Oct. and 24 Nov. 1992 and on 12 Jan. 1993, 5-week-old 'Alverda' green cauliflower seedlings, raised by a commercial plant grower company, were planted in double rows in the beds at $31.0-\mathrm{cm}$ between-row spacing.

Pesticides labeled for use on cauliflower were applied weekly against fungi and insects. Soil samples for elemental analyses were taken 5 and 42 days after planting (DAP) and after harvest. Dry-matter content and elemental concentrations on recently matured young leaves were determined in midseason and at harvest (Hanlon and de Vore, 1989). In the second planting (24 Nov.), six plants were cut off at soil level at harvest (77 DAP), then separated into leaves, stems, and curds that were weighed separately. Dry-matter and elemental concentrations were then determined on the plant organs.

Curds were harvested from a 3.9-m-long section and graded according to U.S. Grade Standards for cauliflower [U.S. Dept. of Agriculture (USDA), 1981]. Wrapper leaves were trimmed at the maximum curd diameter and curds $\geq 0.34 \mathrm{~kg}$ and $\geq 11.5 \mathrm{~cm}$ in diameter were considered marketable size. Harvest period for the 1 Oct. 1992 planting was from 17 Dec. 1992 to 12 Jan. 1993, for the 24 Nov. 1992 planting from $1 \mathrm{Feb}$. to $1 \mathrm{Mar}$. 1993, and for the 12 Jan. 1993 planting from 23 Mar. to 2 Apr. 1993.

All data were analyzed by analysis of variance (SAS Institute, 1988). Where appropriate, regression analyses were performed to test the effect of the $\mathrm{N}$ and $\mathrm{K}$ rates. Arcsin transformations were performed before analyses on data for percentage of marketables.

\section{Results}

Monthly average maximum temperatures were above the 39-year average in November, December, and January and below the average in October, February, and March (Table 1). Monthly average minimum temperatures were above the 39-year average in November and January and below the average in October, 
December, and February. The high rainfall in January did not damage the crop; plant pests, pathogens, and insects were controlled in all three plantings. The length of season from transplanting to the last harvest and the duration of harvest period differed for the three plantings. The total length of the season was 99 days for the October, 90 days for the November, and 80 days for the January planting. The harvest period was 22 days for the October, 25 days for the November, and 11 days for the January planting.

Planting dates significantly affected the marketable yields of green cauliflower (Tables 2 and 3). Yields, averaged over the plant spacings and $\mathrm{N}$ and $\mathrm{K}$ rates, were highest in the January planting and lowest in the October planting. In the October planting, only $16 \%$ of the plants reached marketable size $(\geq 0.34 \mathrm{~kg})$ curds and a very large proportion of curds were bracty, i.e., leaves growing through and above the curds (USDA, 1981). Even in the November planting, only about half as many plants had marketable curds as in the January planting (Table 3). Marketable yields were $17 \%$ higher at the 38.0- than at the 31.0-cm spacing. The proportion of plants with marketable curds and average weight per curd were higher at the 38.0- than at the $31.0-\mathrm{cm}$ spacing (Table 3 ). With the three $\mathrm{N}$ and $\mathrm{K}$ rates, we were capable of partitioning the linear and quadratic effects of $\mathrm{N}$ and $\mathrm{K}$ on marketable yields. Yields increased linearly and quadratically with increasing $\mathrm{N}$ rates (Table 3 ). The quadratic equation was: $\mathrm{Y}=-3.642+0.0671 \mathrm{X}$ $-0.000085 \mathrm{X}^{2}(P \leq 0.01)$, where $\mathrm{Y}$ is the marketable yield in th $\mathrm{a}^{-1}$ and $\mathrm{X}$ is the $\mathrm{N}$ rate in $\mathrm{kg} \cdot \mathrm{ha}^{-1}$. Number of plants with marketable curds also increased linearly and quadratically, $\mathrm{Y}=-5.448+0.1 \mathrm{X}-0.000147 \mathrm{X}^{2}(P \leq$ $0.01)$, with increasing $\mathrm{N}$ rates. The increase in weight per curd with $\mathrm{N}$ rates was linear and best described by the equation: $\mathrm{Y}=0.401+$ $0.000147 \mathrm{X}^{2}(P \leq 0.01)$. Potassium rates had no significant effect on yield or on curd size.

Only the interaction of planting dates with the $\mathrm{N}$ rates was significant (Table 4). At each planting date, marketable yields and the proportion of plants with marketable curds increased as the $\mathrm{N}$ rate increased. Yields ranged from $0.5 \mathrm{t} \cdot \mathrm{ha}^{-1}$ and $3 \%$ of the plants with marketable curds in the October planting with $\mathrm{N}$ at $98 \mathrm{~kg} \cdot \mathrm{ha}^{-1}$ to $12.9 \mathrm{t} \cdot \mathrm{ha}^{-1}$ and $71.0 \%$ of the plants with marketable curds in the January planting with $\mathrm{N}$ at $294 \mathrm{~kg} \cdot \mathrm{ha}^{-1}$. In the October and November plantings, the yield increase with $\mathrm{N}$ rates was linear, and in the January planting it was linear and quadratic.

Fresh weight of whole plants and plant organs and the proportion of curd, leaves, and stem in the total plant weight at harvest was similar at the two in-row spacings. To illustrate the effect of $\mathrm{N}$ and $\mathrm{K}$ rates on the weight and on the proportions of plant organs and on the elemental concentrations in the shoots and in the curds, only the data for the low (98 $\left.\mathrm{kg} \cdot \mathrm{ha}^{-1}\right)$ and high $\left(294 \mathrm{~kg} \cdot \mathrm{ha}^{-1}\right) \mathrm{N}$ and $\mathrm{K}$ rates are presented (Tables 5 and 6 ). Total plant weight and weight of leaves and stems was higher with $\mathrm{N}$ at 294 than at $98 \mathrm{~kg} \cdot \mathrm{ha}^{-1}$ (Table 5). Weight of curds was similar with both $\mathrm{N}$
Table 1. Mean monthly maximum and minimum air temperature $\left({ }^{\circ} \mathrm{C}\right)$ and rainfall $(\mathrm{mm})$ from Aug. 1992 to Apr. 1993 at the Gulf Coast Research and Education Center, Bradenton ${ }^{z}$, Fla. ${ }^{y}$

\begin{tabular}{|c|c|c|c|c|c|c|}
\hline \multirow{3}{*}{$\begin{array}{l}\text { Year } \\
\text { and } \\
\text { month }\end{array}$} & \multicolumn{4}{|c|}{ Temp $\left({ }^{\circ} \mathrm{C}\right)$} & & \\
\hline & \multicolumn{2}{|c|}{ Actual } & \multicolumn{2}{|c|}{ 39-year mean } & \multicolumn{2}{|c|}{ Rainfall (mm) } \\
\hline & Max & Min & Max & Min & Actual & 39-year mean \\
\hline \multicolumn{7}{|c|}{1992} \\
\hline August & 32.8 & 22.2 & 33.3 & 22.8 & 260 & 249 \\
\hline September & 31.8 & 21.7 & 32.8 & 22.2 & 99 & 207 \\
\hline October & 28.9 & 17.8 & 29.4 & 17.8 & 81 & 74 \\
\hline November & 26.7 & 17.2 & 26.1 & 14.4 & 46 & 51 \\
\hline December & 25.0 & 12.7 & 23.3 & 16.7 & 40 & 59 \\
\hline \multicolumn{7}{|c|}{1993} \\
\hline January & 24.4 & 15.0 & 22.2 & 10.0 & 229 & 70 \\
\hline February & 22.8 & 10.6 & 23.3 & 11.1 & 52 & 78 \\
\hline March & 24.4 & 12.8 & 25.0 & 12.8 & 59 & 85 \\
\hline April $^{\mathrm{x}}$ & 28.1 & 18.1 & 27.8 & 15.6 & 46 & 43 \\
\hline
\end{tabular}

${ }^{2}$ Lat. $27^{\circ} 30^{\prime} \mathrm{N}$; long. $83^{\circ} 30^{\prime} \mathrm{W}$.

'Data from Stanley (1993).

${ }^{\mathrm{x} A c t u a l, ~ 1-2 ~ A p r . ~ o n l y ; ~ m e a n, ~ 1-30 ~ A p r . ~}$

Table 2. Analysis of variance for green cauliflower marketable yields for three planting dates, two plant spacings, and three $\mathrm{N}$ and $\mathrm{K}$ rates.

\begin{tabular}{lrrrr}
\hline \hline Variable & df & \multicolumn{1}{c}{ MS $^{z}$} & F value & $P>\mathrm{F}$ \\
\hline Replication (R) & 2 & 0.637 & 0.51 & 0.6009 \\
Planting date (D) & 2 & 229.181 & 184.56 & 0.0001 \\
$\mathrm{D} \times \mathrm{R}$ (Error 1) & 4 & 3.649 & & \\
Spacing (S) & 1 & 11.533 & 9.29 & 0.0032 \\
$\mathrm{D} \times \mathrm{S}$ & 2 & 3.886 & 3.13 & 0.0498 \\
$\mathrm{D} \times \mathrm{R} \times \mathrm{S}$ (Error 2) & 6 & 1.831 & & \\
$\mathrm{Nitrogen}$ rate (N) & 2 & 222.130 & 178.88 & 0.0001 \\
$\mathrm{D} \times \mathrm{N}$ & 4 & 7.144 & 5.75 & 0.0004 \\
$\mathrm{~N} \times \mathrm{S}$ & 2 & 0.656 & 0.53 & 0.5918 \\
$\mathrm{D} \times \mathrm{N} \times \mathrm{S}$ & 4 & 2.091 & 1.68 & 0.1632 \\
$\mathrm{D} \times \mathrm{S} \times \mathrm{R} \times \mathrm{N}$ (Error 3) & 24 & 2.429 & & \\
Potassium rate (K) & 2 & 0.938 & 0.76 & 0.4736 \\
$\mathrm{D} \times \mathrm{K}$ & 4 & 0.707 & 0.57 & 0.6854 \\
$\mathrm{~K} \times \mathrm{S}$ & 2 & 3.189 & 2.57 & 0.0837 \\
$\mathrm{~N} \times \mathrm{K}$ & 4 & 2.038 & 1.64 & 0.1732 \\
$\mathrm{D} \times \mathrm{K} \times \mathrm{S}$ & 4 & 1.826 & 1.47 & 0.2201 \\
$\mathrm{D} \times \mathrm{N} \times \mathrm{K}$ & 8 & 0.581 & 0.47 & 0.8750 \\
$\mathrm{~N} \times \mathrm{K} \times \mathrm{S}$ & 4 & 2.463 & 1.98 & 0.1061 \\
$\mathrm{D} \times \mathrm{N} \times \mathrm{K} \times \mathrm{S}$ & 8 & 1.223 & 0.98 & 0.4551 \\
$\mathrm{D} \times \mathrm{S} \times \mathrm{N} \times \mathrm{K} \times \mathrm{R}$ (Error 4) & 72 & 1.241 & & \\
\hline
\end{tabular}

${ }^{\mathrm{z}} \mathrm{MS}=$ mean squares (rounded to three decimals).

Table 3. Main effect of planting date, within-row plant spacing, and $\mathrm{N}$ and $\mathrm{K}$ rates on 'Alverda' green cauliflower yields.

\begin{tabular}{|c|c|c|c|c|}
\hline \multirow[b]{2}{*}{ Variable } & \multirow{2}{*}{$\begin{array}{c}\text { Marketable } \\
\text { yield } \\
\left(\mathrm{t} \cdot \mathrm{ha}^{-1}\right)\end{array}$} & \multicolumn{2}{|c|}{ Plants with marketable curds } & \multirow{2}{*}{$\begin{array}{c}\text { Wt/curd } \\
(\mathrm{kg})\end{array}$} \\
\hline & & No./ha $(1000 \mathrm{~s})^{\mathrm{z}}$ & $(\%)$ & \\
\hline \multicolumn{5}{|l|}{ Planting date (D) } \\
\hline 1 Oct. 1992 & 2.9 & 6.1 & 16.1 & 0.48 \\
\hline 24 Nov. 1992 & 4.8 & 10.8 & 28.2 & 0.44 \\
\hline 12 Jan. 1993 & 9.5 & 20.6 & 54.3 & 0.46 \\
\hline $\operatorname{LSD}_{0.05}{ }^{\mathrm{y}}$ & 1.72 & 2.64 & 9.25 & NS \\
\hline \multicolumn{5}{|c|}{ Within-row spacing $(\mathrm{S})$} \\
\hline $30.5 \mathrm{~cm}$ & 5.3 & 13.0 & 30.2 & 0.41 \\
\hline $38.0 \mathrm{~cm}$ & 6.2 & 12.0 & 34.9 & 0.52 \\
\hline $\operatorname{LSD}_{0.05}{ }^{\mathrm{y}}$ & 0.80 & 0.72 & 3.19 & 0.06 \\
\hline \multicolumn{5}{|l|}{$\mathrm{N}\left(\mathrm{kg} \cdot \mathrm{ha}^{-1}\right)$} \\
\hline 98 & 2.1 & 4.9 & 13.0 & 0.42 \\
\hline 196 & 6.3 & 14.1 & 36.9 & 0.45 \\
\hline 294 & 8.8 & 18.6 & 48.7 & 0.47 \\
\hline \multirow[t]{2}{*}{ Significance } & $\mathrm{L}^{* *}$ & $\mathrm{~L}^{* *}$ & $\mathrm{~L}^{* *}$ & $\mathrm{~L}^{* *}$ \\
\hline & $\mathrm{Q}^{* *}$ & $\mathrm{Q}^{* *}$ & $\mathrm{Q}^{* *}$ & $\mathrm{Q}^{\mathrm{NS}}$ \\
\hline \multicolumn{5}{|l|}{ Interaction $^{\mathrm{x}}$} \\
\hline $\mathrm{D} \times \mathrm{N}$ & $* *$ & $* *$ & $* *$ & NS \\
\hline
\end{tabular}

${ }^{2}$ Plant population/ha: 43,000 at 30.5-cm and 34,400 at 38.0-cm within-row spacing.

${ }^{\mathrm{y}_{\mathrm{LSD}}}$ at $P \leq 0.05$ is significant as indicated or nonsignificant.

${ }^{x}$ No other interactions were significant.

Ns, ${ }^{*}, * *$ Nonsignificant or significant at $P<0.05$ or 0.01 , respectively; $\mathrm{L}=$ linear, $\mathrm{Q}=$ quadratic. 
rates $\left(\mathrm{kg} \cdot \mathrm{ha}^{-1}\right), 0.62 \mathrm{~kg}$ with 98 and $0.53 \mathrm{~kg}$ with 294. Effect of K rates on the fresh weight of plants and leaves and stem was opposite to the N-rate effects. Total weight of plant, leaves, and stem were higher with $\mathrm{K}$ at 98 than at 294 $\mathrm{kg} \cdot \mathrm{ha}^{-1}$ (Table 5).

Dry-matter content in curd, leaves, and stem was similar with $\mathrm{N}$ at 98 or $294 \mathrm{~kg} \cdot \mathrm{ha}^{-1}$ (Table 6). Nitrogen concentrations in curd, leaves, and stem, and $\mathrm{P}, \mathrm{Fe}$, and $\mathrm{Zn}$ in curd and Mn concentration in leaves were higher with $\mathrm{N}$ at 294 than at $98 \mathrm{~kg} \cdot \mathrm{ha}^{-1}$ (Table 6). The concentrations of all other macro and micronutrients in curds, leaves, and stems were similar with low or high $\mathrm{N}$ rates. Potassium rates affected $\mathrm{N}$ and $\mathrm{K}$ concentrations in leaves and $\mathrm{N}$ concentrations in stems; in leaves, $\mathrm{N}$ concentration was $4.42 \%$ and $\mathrm{K}$ concentration $1.79 \%$ with $\mathrm{K}$ at $98 \mathrm{~kg} \cdot \mathrm{ha}^{-1}$, and $3.22 \% \mathrm{~N}$ and $3.34 \% \mathrm{~K}$ with $\mathrm{K}$ at $294 \mathrm{~kg} \cdot \mathrm{ha}^{-1}$. In stems, $\mathrm{N}$ concentration was $3.79 \%$ with $\mathrm{K}$ at $98 \mathrm{~kg} \cdot \mathrm{ha}^{-1}$ and $2.62 \%$ with $\mathrm{K}$ at $294 \mathrm{~kg} \cdot \mathrm{ha}^{-1}$.

In the soil, $\mathrm{pH}$ decreased with increasing $\mathrm{N}$ rates at 5 and 42 days after planting (DAP), but residual $\mathrm{pH}$ (i.e., at 90 DAP) was the same with all three $\mathrm{N}$ rates (Table 7). Nitrate- and $\mathrm{NH}_{4}-\mathrm{N}$ concentrations also increased with increasing $\mathrm{N}$ rates at 5 and 42 DAP, but residual $\mathrm{N}$ concentrations were similar. Soil K concentrations increased with increasing $\mathrm{K}$ rates at all three sampling dates.

\section{Discussion}

'Alverda' green cauliflower yields were much below the yield of 'Snow Crown Hybrid' white cauliflower at this location with similar $\mathrm{N}$ and $\mathrm{K}$ rates (Csizinszky, 1987; Csizinszky and Schuster, 1988). For example, in the October planting, the best green cauliflower yield of $5.2 \mathrm{t} \cdot \mathrm{ha}^{-1}$ (Table 3) was only $35 \%$ and in the spring (January to April) planting only $60 \%$ of the white cauliflower yield reported in previous years. Furthermore, green cauliflower had a slower curd development when planted in October and November than in January, as indicated by the length of the growing and harvesting season at the three planting dates. The reason for the poor yields in the fall plantings may be the high day and night temperatures during seedling development. Skapski and Oyer (1964), in a threeseasons-long experiment with 'Snowball Imperial' and 'Snowball A' cauliflower, found that curd initiation was inhibited when transplants were kept at $>21.1{ }^{\circ} \mathrm{C}$. Liptay (1981) reported that some cauliflower cultivars required a longer period to form curds under high than under moderate or cool conditions. In my case, green cauliflower seedlings had optimum day and night temperatures for growth and development only in the January planting when sown at the end of November (Table 1). Therefore, in areas with similar climatic conditions to those described herein, green cauliflower should be planted during the cooler winter months for maximum yields. Another advantage of the winter-spring timing of green flower production would be the reduced pesticide and irrigation costs due to a shorter growing period than in an early or late fall planting.

Table 4. Interaction of planting date and $\mathrm{N}$ rate on green cauliflower yield and on the proportion of plants with marketable curds.

\begin{tabular}{|c|c|c|c|c|c|}
\hline \multirow[b]{2}{*}{ Planting date } & \multicolumn{3}{|c|}{$\mathrm{N}\left(\mathrm{kg} \cdot \mathrm{ha} \mathrm{a}^{-1}\right)^{\mathrm{z}}$} & \multicolumn{2}{|c|}{ Significance } \\
\hline & 98 & 196 & 294 & $\mathrm{~L}$ & $\mathrm{Q}$ \\
\hline \multicolumn{6}{|c|}{$t \cdot h a^{-I z}$} \\
\hline 1 Oct. 1992 & $0.5 \mathrm{~b}^{\mathrm{y}}$ & $3.0 \mathrm{~b}$ & $5.2 \mathrm{~b}$ & $* *$ & NS \\
\hline 24 Nov. 1992 & $1.1 \mathrm{~b}$ & $5.0 \mathrm{~b}$ & $8.2 \mathrm{~b}$ & $* *$ & NS \\
\hline 12 Jan. 1993 & $4.8 \mathrm{a}$ & $10.8 \mathrm{a}$ & $12.9 \mathrm{a}$ & $* *$ & ** \\
\hline \multicolumn{6}{|c|}{ Percentage of plants with marketable curds (\%) } \\
\hline 1 Oct. 1992 & $3.0 \mathrm{~b}$ & $17.0 \mathrm{~b}$ & $28.0 \mathrm{~b}$ & $* *$ & NS \\
\hline 24 Nov. 1992 & $7.0 \mathrm{~b}$ & $31.0 \mathrm{~b}$ & $47.0 \mathrm{~b}$ & $* *$ & NS \\
\hline 12 Jan. 1993 & $29.0 \mathrm{a}$ & $63.0 \mathrm{a}$ & $71.0 \mathrm{a}$ & $* *$ & $* *$ \\
\hline
\end{tabular}

${ }^{2}$ Yields for each planting date were averaged over two within-row plant spacings, three $\mathrm{K}$ rates, and three replications.

yMean separation between planting dates for the same $\mathrm{N}$ rate by Duncan's multiple range test, $P \leq 0.05$.

Ns, ${ }^{* *}$ Response to $\mathrm{N}$ rates is nonsignificant or significant at $P \leq 0.01 ; \mathrm{L}=$ linear, $\mathrm{Q}=$ quadratic.

Table 5. Fresh weight and proportion of whole plants and plant organs of green cauliflower at harvest as affected by plant spacing and $\mathrm{N}$ and $\mathrm{K}$ rates in Nov. 1992 planting.

\begin{tabular}{|c|c|c|c|c|}
\hline \multirow{2}{*}{$\begin{array}{l}\text { Fertilizer } \\
\text { applied } \\
\left(\mathrm{kg}^{\circ} \mathrm{ha}^{-1}\right) \\
\end{array}$} & \multicolumn{4}{|c|}{ Wt $[\mathrm{kg}(\%)]$} \\
\hline & Total plant & Curd & Leaves & Stem \\
\hline \multicolumn{5}{|l|}{$\mathrm{N}$} \\
\hline 98 & $2.70(100)^{z}$ & $0.62(23)$ & $1.72(64)$ & $0.36(13)$ \\
\hline 294 & $3.45(100)$ & $0.53(15)$ & $2.46(71)$ & $0.46(13)$ \\
\hline $\mathrm{Sx}^{-}$ & $*$ & NS & $*$ & $*$ \\
\hline \multicolumn{5}{|l|}{$\mathrm{K}$} \\
\hline 98 & $3.58(100)^{y}$ & $0.55(15)$ & $2.56(72)$ & 0.47 (13) \\
\hline 294 & $3.01(100)$ & $0.56(19)$ & $2.04(68)$ & $0.41(14)$ \\
\hline $\mathrm{Sx}^{-}$ & $*$ & NS & $*$ & $*$ \\
\hline
\end{tabular}

${ }^{\mathrm{z}}$ Averaged over two plant spacings, three $\mathrm{K}$ rates, and three replications.

${ }^{y}$ Averaged over two plant spacings, three $\mathrm{N}$ rates, and three replications.

Ns, "Mean difference is nonsignificant or significant at $P \leq 0.05$.

Table 6. Dry-matter (DM) and elemental concentrations in green cauliflower curds and shoots at harvest (Nov. 1992 plantings).

\begin{tabular}{|c|c|c|c|c|c|c|c|}
\hline \multirow{3}{*}{$\begin{array}{l}\mathrm{N} \text { applied } \\
\left(\mathrm{kg} \mathrm{ha}^{-1}\right)\end{array}$} & \multirow{3}{*}{$\begin{array}{l}\text { DM } \\
(\%)\end{array}$} & \multicolumn{6}{|c|}{ Element } \\
\hline & & $\mathrm{N}$ & $\mathrm{P}$ & $\mathrm{K}$ & $\mathrm{Fe}$ & $\mathrm{Mn}$ & $\mathrm{Zn}$ \\
\hline & & \multicolumn{3}{|c|}{$\left(\mathrm{g} / 100 \mathrm{~g}^{\mathrm{z}}\right)$} & \multicolumn{3}{|c|}{$\left(\mathrm{mg} \cdot \mathrm{kg}^{-1 \mathrm{z}}\right)$} \\
\hline \multicolumn{8}{|c|}{ Curd $y$} \\
\hline 98 & 10.77 & 3.66 & 0.51 & 2.82 & 39.0 & 18.8 & 37.0 \\
\hline 294 & 9.40 & 5.50 & 0.62 & 2.83 & 52.8 & 21.9 & 56.7 \\
\hline $\mathrm{Sx}^{-}$ & NS & $*$ & $*$ & NS & $*$ & NS & $*$ \\
\hline \multicolumn{8}{|c|}{ Leaf" } \\
\hline 98 & 10.91 & 2.29 & 0.33 & 3.29 & 42.3 & 45.8 & 30.9 \\
\hline 294 & 9.18 & 4.29 & 0.39 & 2.59 & 52.9 & 61.7 & 36.6 \\
\hline $\mathrm{Sx}^{-}$ & NS & $*$ & NS & NS & NS & $*$ & NS \\
\hline \multicolumn{8}{|c|}{ Stem $^{y}$} \\
\hline 98 & 12.90 & 1.35 & 0.47 & 4.43 & 31.5 & 13.8 & 46.7 \\
\hline 294 & 10.97 & 3.58 & 0.48 & 4.62 & 33.8 & 17.9 & 43.5 \\
\hline $\mathrm{Sx}^{-}$ & NS & $*$ & NS & NS & NS & NS & NS \\
\hline
\end{tabular}

${ }^{2}$ Dry weight basis.

${ }^{\mathrm{y}}$ Averaged over two within-row spacings, three $\mathrm{K}$ rates, and three replications.

Ns, * Mean difference is nonsignificant or significant at $P \leq 0.05$.

The increased curd size of green cauliflower at the wider $38-\mathrm{cm}$ spacing is in agreement with previously published results for white cauliflower response to plant spacing (Csizinszky, 1982; Dufault and Waters, 1985).

Green cauliflower yields, regardless of the planting dates, increased with increasing $\mathrm{N}$ rates and were highest at $294 \mathrm{~kg} \cdot \mathrm{ha}^{-1}$. Hara and Sonoda (1982) found that, in cabbage (Brassica oleracea L. Capitata Group), high $\mathrm{N}$ rates counteracted the adverse effect of high temperatures on head development and size. The high $\mathrm{N}$ requirement of green cauliflower for good yield is in agreement with my previous study on $\mathrm{N}$ requirement of white cauliflower (Csizinszky, 1987). In that study, white cauli- flower yields were best with $\mathrm{N}$ at $256 \mathrm{~kg} \cdot \mathrm{ha}^{-1}$. However, under cool climatic conditions green cauliflower may have a lower $\mathrm{N}$ requirement than in this study, because, in the northern areas of the United States and in Canada, white cauliflower yields were maximized with $\mathrm{N}$ at 112 kg.ha ${ }^{-1}$ (Cutcliffe and Munro, 1976; Dufault and Waters, 1985). In spite of the high N rates and the wide spacing, hollow-stem was absent on the curds in all of the three planting dates. Scaife and Wurr (1990) reported that in their studies, maximum number of curds with hollow-stem was found with $\mathrm{N}$ at $150 \mathrm{~kg} \cdot \mathrm{ha}^{-1}$ with irrigation and wide spacing. Apparently, the 'Alverda' green cauliflower can be grown without hollow-stem with the high (294 
Table 7. Seasonal variation of $\mathrm{pH}$ and ionic concentrations in soil. Fall-Winter (November to January) 1992 93.

\begin{tabular}{|c|c|c|c|}
\hline \multirow{2}{*}{$\begin{array}{l}\text { Fertilizer } \\
\text { applied } \\
\left(\mathrm{kg} \mathrm{ha}^{-1}\right)\end{array}$} & \multicolumn{3}{|c|}{ DAP $^{z}$} \\
\hline & 5 & 42 & 90 \\
\hline \multicolumn{4}{|c|}{$p H^{y}$} \\
\hline \multicolumn{4}{|l|}{$\mathrm{N}$} \\
\hline 98 & 6.24 & 6.32 & 6.39 \\
\hline 196 & 6.19 & 6.08 & 6.39 \\
\hline 294 & 5.93 & 5.84 & 6.06 \\
\hline \multicolumn{4}{|c|}{ Significance } \\
\hline $\mathrm{L}$ & $*$ & $*$ & NS \\
\hline Q & $*$ & $*$ & NS \\
\hline \multicolumn{4}{|c|}{$\mathrm{NH}_{4}^{+}-\mathrm{N}\left(m g \cdot \mathrm{L}^{-1}\right)^{y}$} \\
\hline 98 & 16.3 & 4.4 & 1.3 \\
\hline 196 & 31.6 & 12.2 & 1.6 \\
\hline 294 & 45.0 & 28.4 & 3.4 \\
\hline \multicolumn{4}{|c|}{ Significance } \\
\hline $\mathrm{L}$ & $*$ & $*$ & NS \\
\hline Q & $*$ & $*$ & NS \\
\hline \multicolumn{4}{|c|}{$\mathrm{NO}_{3}-\mathrm{N}\left(m g \cdot L^{-1}\right)^{y}$} \\
\hline 98 & 18.7 & 3.7 & 0.2 \\
\hline 196 & 38.4 & 15.6 & 0.3 \\
\hline 294 & 47.1 & 25.9 & 2.1 \\
\hline \multicolumn{4}{|c|}{ Significance } \\
\hline $\mathrm{L}$ & $*$ & $*$ & NS \\
\hline Q & $*$ & $*$ & NS \\
\hline \multicolumn{4}{|c|}{$K+\left(m g \cdot L^{-1}\right)^{x}$} \\
\hline \multicolumn{4}{|l|}{ K } \\
\hline 98 & 131.0 & 63.0 & 11.0 \\
\hline 196 & 231.0 & 136.0 & 23.0 \\
\hline 294 & 436.0 & 185.0 & 82.0 \\
\hline \multicolumn{4}{|c|}{ Significance } \\
\hline $\mathrm{L}$ & $*$ & $*$ & $*$ \\
\hline Q & $*$ & $*$ & $*$ \\
\hline
\end{tabular}

$\mathrm{kg} \cdot \mathrm{ha}^{-1}$ ) $\mathrm{N}$ rate and at the $38-\mathrm{cm}$, within-row spacing. Increased $\mathrm{N}$ rates also had a positive effect on the uptake of $\mathrm{N}, \mathrm{P}, \mathrm{Fe}$, and $\mathrm{Zn}$ in the curds; $\mathrm{N}$ and $\mathrm{Mn}$ in the leaf; and $\mathrm{N}$ in the stem. At the low $\mathrm{N}$ rate the curd was a sink for $\mathrm{N}$, since it contained $3.66 \% \mathrm{~N}$, while the stem contained only $1.35 \%$ and the leaves $2.29 \%$. Residual soil N concentrations at the end of the season were very low even at the high $\mathrm{N}$ rate, which provides further support for the high $\mathrm{N}$ requirement of this crop.

Green cauliflower had a low $\mathrm{K}$ requirement. The residual $\mathrm{K}\left(14.7 \mathrm{mg} \cdot \mathrm{kg}^{-1}\right)$ in the soil and the $98 \mathrm{~kg} \cdot \mathrm{ha}^{-1}$ applied from the $\mathrm{KCl}$ and $\mathrm{K}_{2} \mathrm{SO}_{4}$ sources were sufficient for good yields, provided $\mathrm{N}$ was applied at the high rate. In other studies, white cauliflower yields were maximized with $\mathrm{K}$ at $93 \mathrm{~kg} \cdot \mathrm{ha}^{-1}$ (Cutcliffe and Munro, 1976) and 'Green Valiant' broccoli yields at $83 \mathrm{~kg} \cdot \mathrm{ha}^{-1}$ (Csizinszky, 1987). Yields did not increase with increasing $\mathrm{K}$ rates, and residual $\mathrm{K}$ concentrations in the soil were high after the harvest. conditions, seedling growth and planting of green cauliflower should be timed when minimum temperatures fall to $\left\langle 21{ }^{\circ} \mathrm{C}\right.$. The crop requires large amounts of $\mathrm{N}$ since, even under favorable climatic conditions (January to April), only $63 \%$ of the plants had marketable curds with $\mathrm{N}$ at $196 \mathrm{~kg} \cdot \mathrm{ha}^{-1}$, but $71 \%$ of the plants had marketable curds with $\mathrm{N}$ at 294 $\mathrm{kg} \cdot \mathrm{ha}^{-1}$. The crop had a low demand for $\mathrm{K}$ and should be planted at $38-\mathrm{cm}$, within-row spacing to maximize marketable yields.

\section{Literature Cited}

Csizinszky, A.A. 1982. Effect of fertilizer placement and in-row spacing on cauliflower yield. Proc. Fla. State Hort. Soc. 95:328-330.
In summary, under warm, humid climatic
Csizinszky, A.A. 1987. Nutrition of cole crops with the full-bed polyethylene mulch system in west-central Florida. J. Plant Nutr. 10:14891497.

Csizinszky, A.A. 1995. Green cauliflower (Broccoflower) variety evaluation. Univ. of Florida Gulf Coast Res. \& Educ. Ctr.-Bradenton Res. Rpt. BRA-1995-16.

Csizinszky, A.A. 1996. Green cauliflower (Broccoflower) Brassica oleracea L. Botrytis group, cv. Alverda, response to $\mathrm{N}$ and $\mathrm{K}$ rates and plant spacing on sand. Proc. Fla. State Hort. Soc. 108:(In press.)

Csizinszky, A.A. and D.J. Schuster. 1988. Impact of insecticide schedule, $\mathrm{N}$ and $\mathrm{K}$ rates and transplant container cell size on cauliflower yield. Appl. Agr. Res. 3:12-16.

Cutcliffe, J.A. and D.C. Munro. 1976. Effects of nitrogen, phosphorous and potassium on yield and maturity of cauliflower. Can. J. Plant Sci. 56:127-131.

Dufault, R.J. and L. Waters, Jr. 1985. Interaction of nitrogen fertility and plant populations on transplanted broccoli and cauliflower yields. HortScience 20:127-128.

Geraldson, C.M., A.J. Overman, and J.P. Jones. 1965. Combination of high analysis fertilizer, plastic mulch, and fumigation for tomato production on old agricultural land. Proc. Soil \& Crop Sci. Soc. Fla. 28:18-24.

Hanlon, E.A. and J.M. de Vore. 1989. Chemical procedures and training material. Florida Coop. Ext. Serv. Circ. 812, Gainesville.

Hanlon, E.A., G. Kidder, and B.L. McNeal. 1990. Soil, container and water testing. Fla. Coop. Ext. Circ. 817, Gainesville.

Hara, T. and Y. Sonoda. 1982. Cabbage head development as affected by nitrogen and temperature. Soil Sci. Plant Nutr. 28:109-117.

Liptay, A. 1981. Cauliflower: Curd initiation and timing of production in a high-temperature growing season. Acta Hort. 122:47-52.

Long, E. 1994. Caulis, 5-month cut. Grower (UK) 121:9-10.

Montecalvo, J. 1989. Report of vitamin analysis for broccoli and cauliflower. California Polytechnic State Univ., San Luis Obispo.

SAS Institute. 1988. SAS/STAT user's guide. Release 6.03 ed. SAS Inst., Cary, N.C.

Scaife, A. and D.C.E. Wurr. 1990. Effects of nitrogen and irrigation on hollow stem of cauliflower (Brassica oleracea var. botrytis). J. Hort. Sci. 65:25-29.

Skapski, H. and E.B. Oyer. 1964. The influence of pre-transplanting variables on the growth and development of cauliflower plants. Proc. Amer. Soc. Hort. Sci. 85:374-385.

Stanley, C.D. 1993. Weather report for 1992. Bradenton Gulf Coast Res. \& Educ. Ctr. Res. Rpt. BRA 1993-1.

Tecator. 1987. Determination of Kjeldahl nitrogen with the kjeltic system 1026. Tecator, Herndon, Va.

U.S. Dept. of Agriculture. 1981. United States standards for grades of cauliflower. U.S. Dept. Agr., Agr. Mktg. Serv., Washington, D.C. 